\title{
A DIGCOMP 1.0 és a DIGCOMP 2.0
}

\section{DIGCOMP: Keretrendszer a digitális kompetencia fejlesztésére és értelmezésére}

\subsection{Bevezetés, elözmények bemutatása}

2006-os európai ajánlásokban (Europian Parliament and Council, 2006) 8 kulcskompetenciát határoztak meg, amelyek az élethosszig tartó tanulást szolgálják az Európai Unióban. Ezek a következők két nagyobb területre sorolva (Europian Commission, é.n.;):

I. A ,hagyományos” képességek csoportban:

1. az anyanyelv illetve idegen nyelveken folytatott kommunikáció képessége;

2. a digitális készségek;

3. az írni és olvasni tudás képessége;

4. a matematikai és természettudományos/müszaki készségek;

II. Az ún. horizontális képességek közé pedig:

1. a tanulni tudás képességét; 
2. a társadalmi és állampolgári felelősségvállalás képességét;

3. a kezdeményezö- és vállalkozókészséget; valamint

4. a kulturális tudatosságot sorolják. ${ }^{1}$

A Digital kompetencia egyik definíciója: az IKT eszközök magabiztos, kreatív és kritikus használata, annak érdekében, hogy a polgárok a munkájukkal kapcsolatos célokat elérjék, a foglalkoztatásukat biztosítsák. Valamint elengedhetetlen szükséglet a tanuláshoz, a szabadidő eltöltéshez és a szociális életben való részvételhez. A digitális kompetencia olyan transzverzális kulcskompetencia, amely mint olyan, lehetővé teszi, hogy egyéb kulcskompetenciákat megszerezzünk (pl.: nyelv, matematika, a tanulás tanulása, a kulturális tudatosság). Összefügg számos 21 . századi készséggel, amelyeket azért kell megszerezni valamennyi polgárnak, hogy aktívan részt tudjon venni a társadalmi és a gazdasági életben. (Ferrari, 2013)

Három célkitüzése volt annak a projektnek, amelyet 2011. január december 2012 között végeztek és alapját képezte a Ferrari által írt dokumentumnak:

- Azonosítani a digitális kompetencia legfontosabb összetevőit a tudás, a készségek és az attitüdök szempontjából.

- Fejleszteni a digitális kompetenciáról szóló leírásokat, amelyek részét képezik majd a fogalmi kereteknek és / vagy irányelveknek. Ezek vegyék figyelembe a jelenleg rendelkezésre álló kereteket.

- Javasolni egy ütemtervet a digitális kompetencia keretrendszer használatára és esetleges felülvizsgálatára. A projekt célja volt, hogy a célok eléréséhez együttmüködés és párbeszéd valósuljon meg európai szinten az érdekeltek között.

\subsection{A digitális kompetencia fejlesztésére és értelmezésére szolgáló DIGCOMP keretrendszerről szóló dokumentum}

Anusca Ferrari készített egy összefoglaló dokumentumot a DIGCOMP digitális kompetencia keretrendszerröl (Ferrari, 2013). Ferrari a dokumentumban bemutatja a DIGCOMP projektet és minden polgár számára ajánlja a kompetencia keretrendszert. Leírja, hogy a digitális kompetencia a nyolc kulcskompetencia egyike, amely szükséges az élethosszig tartó tanuláshoz és nélkülözhetetlen az

\footnotetext{
${ }^{1}$ Wadmin (2009) írása alapján az elnevezések: Az anyanyelvi kommunikáció; Az idegen nyelveken folytatott kommunikáció képessége; A matematikai, természettudományi és technológiai kompetenciák; A digitális kompetencia; A tanulás tanulása; Személyközi és állampolgári kompetenciák; Vállalkozói kompetencia; Kulturális kompetencia.
} 
egyre digitalizáltabb társadalomban való részvételhez. Tudatja, hogy ezek ellenére sok ember nem rendelkezik digitális képességekkel a nemzetközi felmérések és a szakirodalmi források szerint. Hangsúlyozza, hogy annak érdekében, hogy ezt a hiányt pótolni lehessen, szükséges megérteni és meghatározni azt, hogy mit jelent a digitális kompetencia fogalma és tudni kell azt is, hogy ez a kompetencia miként fejleszthető. Ferrari abból a célból, hogy megértesse az emberekkel, hogy mit jelent a digitális kompetencia és miként fejleszthetö, készítette el DIGCOMP: A Framework for Developing and Understanding Digital Competence in Europe címü írását (Ferrari, 2013), amely az európai szakpolitika fontos dokumentumává vált (Komposzt, 2016).

A DIGCOMP-ról szóló dokumentumban különböző aspektusból kerülnek részletezésre a digitális kompetencia összetevői a 21 kompetencia felsorolásával és bemutatásával, továbbá leírja az azokkal kapcsolatos ismereteket, készségeket és attitüdöket. A projekt egy adatgyüjtési fázison (beleértve szakirodalmi áttekintést, esettanulmányok elemzését ás egy on-line felmérést) és az érdekeltekkel folytatott intenzív konzultáción (beleértve szemináriumokat, interjúkat, szakértői véleményeket, előadásokat és konferenciákat) alapult.

A következő részekből épül fel:

- Önértékelési háló a digitális kompetencia öt területén, amelyek esetében három jártassági szint létezik.

- A digitális kompetencia részletes keretrendszerének mélyreható leírása különböző szempontból. Mind a 21 kompetencia bemutatásra kerül egy táblázatban, amelyben szerepel:

- a kompetencia rövid meghatározása;

- a három tudásszint leírása;

- példák a tudásra, készségekre és attitüdökre az adott kompetencia esetében;

- továbbá két példa arra, hogy a tanulás és a foglalkoztatás esetében, milyen speciális alkalmazási területeken lehet hasznosítani az adott kompetenciát.

A dokumentum szerkezeti felépítése az 1. fejezetben található általános bevezetővel indul, amelyben definiálva vannak a célok és módszerek. A 2. fejezet áttekintést ad a DIGCOMP keretrendszerről, amely felvázolja az azonosított területeket és a digitális kompetenciákat, valamint bemutatja az önértékelési hálózatot. A 3. fejezet bemutatja a teljes keretet, amelyben részletezésre kerülnek 
az egyes kompetenciák szintjei: példák, ismeretek, attitüdök és készségek; és a célra való alkalmazhatóság példái. Az I. melléklet a kulcsfontosságú kifejezések glosszáriumát tartalmazza, a II. melléklet a rövid leírással rendelkező összes hatáskör vázlata. A III. melléklet a kompetenciák közötti kereszthivatkozásokat tartalmazza, a IV. melléklet pedig bemutatja a javaslatokat arról, hogyan lehet áttérni a jártassági szintről a következő szintekre, azaz a digitális kompetencia fejlesztésének mutatóit tartalmazza. Az V. melléklet az egész életen át tartó tanuláshoz szükséges kulcskompetenciáknak és a digitális kompetencia kapcsolódásának fontosságát mutatja be.

\subsection{A DIGCOMP-ban megfogalmazott digitális kompetencia területek és kompetenciák}

Az alábbiakban bemutatásra kerül az 5 digitális kompetencia terület és megnevezésre az azokhoz tartozó kompetenciák, amelyek együttesen 21 kompetenciát jelentenek.

1. Információ (Information): azonosítani, megtalálni, letölteni, tárolni, szervezni és elemezni a digitális információkat értékelve annak relevanciáját és célját.

2. Kommunikáció (Communication): digitális környezetben megvalósuló kommunikáció, a források és az online eszközök megosztása, kapcsolódás egymással és digitális eszközökön keresztül megvalósuló kollaboráció és együttmüködés, interakció közösség és a hálózat résztvevői között, interkulturalitás tudatossága.

3. Tartalomlétrehozás (Content-creation): új tartalmak létrehozása és szerkesztése (a szövegektől a képeken át a videóig); a korábbi ismeretek és tartalmak integrációja és újrahasználhatósága; kreatív kifejezések létrehozása, a média-produktumok és programozás; a szellemi tulajdon jogokkal való foglalkozás és azok alkalmazása.

4. Biztonság (Safety): személyiségvédelem, adatvédelem, digitális identitás védelme, a biztonsági intézkedések biztonságos és fenntartható használata.

5. Problémamegoldás (Problem-solving): digitális igények és források meghatározása annak érdekében, hogy megalapozott döntéshozatalra kerülhessen sor a legalkalmasabb digitális eszközök célja vagy szükséglete szerint. Fogalmi problémák digitális eszközökkel való megoldása, a technológiák kreatív használata, technikai problémák megoldása, saját és mások kompetenciájának frissítése és megújítása. 
Az alábbi táblázat a keretrendszer áttekintéséhez nyújt segítséget, bemutatja a kompetenciákat.

\begin{tabular}{|c|c|}
\hline Kompetencia-területek & Kompetenciák \\
\hline 1. Információ & $\begin{array}{l}\text { 1.1. Információ-böngészés, az információ } \\
\text { keresése és szürése } \\
\text { 1.2. Információ-értékelés } \\
\text { 1.3. Az információ tárolása és visszakeresése }\end{array}$ \\
\hline 2. Kommunikáció & $\begin{array}{l}\text { 2.1. Interakció a technológiákon keresztül } \\
\text { 2.2. Információ és tartalommegosztás } \\
\text { 2.3. Online polgári szerepvállalás } \\
\text { 2.4. Digitális csatornákon való együttmüködés } \\
\text { 2.5. Netikett } \\
\text { 2.6. Digitális identitás menedzselése }\end{array}$ \\
\hline $\begin{array}{l}\text { 3. Tartalom } \\
\text { létrehozás }\end{array}$ & $\begin{array}{l}\text { 3.1. Tartalomfejlesztés } \\
\text { 3.2. Integráció és újrahasznosítás } \\
\text { 3.3. Szerzői jog és licenc } \\
\text { 3.4. Programozás }\end{array}$ \\
\hline 4. Biztonság & $\begin{array}{l}\text { 4.1. Eszközök védelme } \\
\text { 4.2. Személyi adatok védelme } \\
\text { 4.3. Egészségvédelem } \\
\text { 4.4. Környezet védelme }\end{array}$ \\
\hline 5. Problémamegoldás & $\begin{array}{l}\text { 5.1. Technikai problémák megoldása } \\
\text { 5.2. A szükségletek és a technológiai válaszok } \\
\text { azonosítása } \\
\text { 5.3. Innovatív és kreatív technológia-használat } \\
\text { 5.4. Digitális kompetencia rész azonosítása }\end{array}$ \\
\hline
\end{tabular}

4. táblázat A DIGCOMP 5 kompetencia területén lévö kompetenciák 


\subsection{A DIGCOMP dimenziói}

A DIGCOMP keretrendszer „héja” öt dimenzióban van felépítve. Ezek a méretek tükrözik a deszkriptorok ${ }^{2}$ különböző aspektusát és a finomság különböző fázisait:

1. dimenzió: a felismert kompetencia területek. (2. táblázat első oszlopa)

2. dimenzió: az egyes területekre vonatkozó kompetenciák. (1. táblázat)

3. dimenzió: az egyes kompetenciákra előirányzott jártassági szintek. (2. táblázat 1. sora)

4. dimenzió: az egyes kompetenciákra vonatkozó ismeretek, készségek és attitüdök példái (a példák nem különböznek a jártassági szinteken).

5. dimenzió: példák a kompetencia alkalmazására különböző célokra. Ezen belül példákat ír le a tanulás és a foglalkoztatás területéről. Más dimenziók is léteznek: Szabadidő; Társadalmi; Vásárlás és eladás; Tanulás; Foglalkoztatás; Polgárság; Jólét.

Az önértékelési háló a keret 1. és 3. dimenzióját tartalmazza. Ez azt jelenti, hogy mindegyik kompetencia területen három szintet különböztethetünk meg, amelyek figyelembe veszik azokat a kompetenciákat, amelyek az adott területhez tartoznak.

\subsection{A DIGCOMP önértékelési hálója}

Az önértékelési háló a digitális kompetencia öt területéből és három képzettségi szintből áll: az A (alapszint), a B (középszint) és a C (haladó szint) között. Az öt területet használták a projekt két fő kimenetének alapjául: az önértékelési háló és a részletes keret. A területek leíráskor a három jártassági szintet mind az öt területre kidolgozták részletesen, hogy általános áttekintést nyújthassanak egy adott terület tartalmáról. Így összegző képet kaphatunk a modellröl, mintegy absztraktabb, általánosabb szinten, hasonló formában, mint ahogyan CEFR került leírásra a nyelvek esetében.

Minden sorban több változat van a szinteknek megfelelően, viszont ezek azonos jellegü tudásra és képességekre vonatkoznak, csak eltérő mélységüek. A 2. táblázatban elolvasható a DIGCOMP önértékelési háló egyes kompetenciaterületeihez és szintjeihez kapcsolódó készségek és képességek saját fordításban.

\footnotetext{
${ }^{2}$ Deszkriptor jelentése: olyan kifejezés, amely a fogalmak leírására és visszakeresésére közvetlenül alkalmas.
} 


\begin{tabular}{|c|c|c|c|}
\hline & A alapszint & B középszint & C haladó szint \\
\hline Információ & $\begin{array}{l}\text { Képes vagyok } \\
\text { keresőmotorral } \\
\text { keresni. Tudom, } \\
\text { hogyan kell } \\
\text { menteni, tárolni a } \\
\text { fájlokat és } \\
\text { tartalmakat (pl.: } \\
\text { szöveg, kép, zene, } \\
\text { videó weblap). } \\
\text { Tudom, miként } \\
\text { lehet előkeresni a } \\
\text { mentett } \\
\text { tartalmakat. Nem } \\
\text { minden on-line } \\
\text { információ } \\
\text { megbízható. }\end{array}$ & $\begin{array}{l}\text { Képes vagyok az } \\
\text { interneten az } \\
\text { információk } \\
\text { böngészésére és on- } \\
\text { line keresésére. } \\
\text { Képes vagyok a } \\
\text { megfelelő } \\
\text { információ } \\
\text { kiválasztására a } \\
\text { találatok közül. } \\
\text { Képes vagyok } \\
\text { különféle } \\
\text { információforrások } \\
\text { össze-hasonlítására. } \\
\text { Tudom, miként kell } \\
\text { menteni, tárolni és } \\
\text { címkézni fájlokat, } \\
\text { tartalmakat és } \\
\text { informá-ciókat és } \\
\text { van saját mentési } \\
\text { stratégiám. Le } \\
\text { tudom kérni és } \\
\text { tudom menedzselni } \\
\text { az információkat és } \\
\text { tartalmakat, amiket } \\
\text { mentettem és } \\
\text { eltároltam. }\end{array}$ & $\begin{array}{l}\text { Számos stratégiát } \\
\text { tudok alkalmazni } \\
\text { az interneten való } \\
\text { keresés és } \\
\text { böngészés során. } \\
\text { Kritikus vagyok a } \\
\text { megtalált } \\
\text { információkkal } \\
\text { szemben. Felül- } \\
\text { vizsgálhatom és } \\
\text { értékelem azok } \\
\text { valóságát és } \\
\text { hitelességét. } \\
\text { Szüröm és } \\
\text { figyelemmel } \\
\text { kísérem az elért } \\
\text { információkat. } \\
\text { Különböző } \\
\text { módszereket és } \\
\text { eszközöket } \\
\text { alkalmazok a } \\
\text { fájlok, tartalmak } \\
\text { és információk } \\
\text { szervezéséhez. } \\
\text { Képes vagyok egy } \\
\text { sorozat stratégiát } \\
\text { alkalmazni a } \\
\text { tartalmak } \\
\text { visszanyeréséhez } \\
\text { és } \\
\text { menedzseléséhez, } \\
\text { amelyeket én vagy } \\
\text { mások tároltak el. } \\
\text { Tudom, kiket kell } \\
\text { követni az on-line } \\
\text { információmegosz } \\
\text { tó helyek (például } \\
\text { mikroblogok } \\
\text { esetében). }\end{array}$ \\
\hline
\end{tabular}




\begin{tabular}{|c|c|c|c|}
\hline & A alapszint & B középszint & C haladó szint \\
\hline $\begin{array}{l}\text { Kommu- } \\
\text { nikáció }\end{array}$ & $\begin{array}{l}\text { Interakcióba } \\
\text { tudok lépni } \\
\text { másokkal, akik az } \\
\text { alapvető } \\
\text { szolgáltatásokat } \\
\text { használják (pl.: } \\
\text { mobil VoIP, chat } \\
\text { és e-mail). } \\
\text { Ismerem az } \\
\text { alapvető } \\
\text { viselkedési } \\
\text { normákat, } \\
\text { amelyeket } \\
\text { alkalmazni szokás } \\
\text { a digitális } \\
\text { kommunikáció } \\
\text { során. Meg tudok } \\
\text { osztani fájlokat és } \\
\text { tartalmakat } \\
\text { másokkal, } \\
\text { egyszerü } \\
\text { technológiákkal. } \\
\text { Ismerem azokat a } \\
\text { technológiákat, } \\
\text { amelyek kellenek } \\
\text { ahhoz, hogy } \\
\text { bizonyos } \\
\text { szolgálta-tásokat } \\
\text { elérjek. Ezek } \\
\text { közül használok } \\
\text { néhányat. Képes } \\
\text { vagyok másokkal } \\
\text { együttmüködni } \\
\text { hagyományos } \\
\text { technológiák } \\
\text { használata esetén. } \\
\text { a digztában vagýlis } \\
\text { megjelenéssel } \\
\end{array}$ & $\begin{array}{l}\text { Különféle digitális } \\
\text { eszközt alkalmazok } \\
\text { arra, hogy } \\
\text { interakcióba } \\
\text { léphessek } \\
\text { másokkal, amelyre } \\
\text { haladó } \\
\text { kommunikációs } \\
\text { alkalmazásokat } \\
\text { használok (pl.: } \\
\text { mobil VoIP, chat és } \\
\text { e-mail). Ismerem az } \\
\text { online etikett } \\
\text { alapelveit és képes } \\
\text { vagyok használni } \\
\text { azokat. Részt } \\
\text { veszek a közösségi } \\
\text { oldalakon és az } \\
\text { online közösségi } \\
\text { térben, ahol } \\
\text { megosztom és } \\
\text { továbbadom a } \\
\text { tudást, a } \\
\text { tartalmakat és az } \\
\text { információkat. } \\
\text { Aktívan használok } \\
\text { néhány alapvető } \\
\text { on-line } \\
\text { szolgáltatást. Képes } \\
\text { vagyok másokkal } \\
\text { együtt, egyszerü } \\
\text { digitális eszközök } \\
\text { segítségével dolgok } \\
\text { létrehozására és } \\
\text { megvitatására. } \\
\text { Képes vagyok } \\
\text { alakítani saját } \\
\text { online digitális } \\
\text { megjelenésemet } \\
\end{array}$ & $\begin{array}{l}\text { Elkötelezett vagyok } \\
\text { az online } \\
\text { kommunikáció } \\
\text { eszközeinek széles } \\
\text { körü használatával } \\
\text { kapcsolatosan (e- } \\
\text { mailek, } \\
\text { beszélgetések, } \\
\text { SMS, azonnali } \\
\text { üzenet-küldés, } \\
\text { blogok, } \\
\text { mikroblogok, SNS). } \\
\text { Az online etikett } \\
\text { különböző } \\
\text { aspektusait } \\
\text { alkalmazhatom } \\
\text { különféle digitális } \\
\text { kommunikációs } \\
\text { terekben és } \\
\text { kontextusok-ban. } \\
\text { Saját stratégiákat } \\
\text { fejlesztettem ki, } \\
\text { hogy felfedezzem a } \\
\text { helytelen } \\
\text { viselkedésformákat. } \\
\text { El tudom fogadni } \\
\text { azokat a digitális } \\
\text { módokat és } \\
\text { kommunikációs } \\
\text { módszereket, } \\
\text { amelyek a } \\
\text { legjobban } \\
\text { illeszkednek az } \\
\text { adott célokhoz. A } \\
\text { kommunikációs } \\
\text { módot és } \\
\text { kommunikációs } \\
\text { utat jól ki tudom } \\
\text { választani az adott }\end{array}$ \\
\hline
\end{tabular}




\begin{tabular}{|c|c|c|c|}
\hline & A alapszint & B középszint & C haladó szint \\
\hline & $\begin{array}{l}\text { (identitással) } \\
\text { kapcsolatos } \\
\text { előnyökkel és } \\
\text { kockázatokkal. }\end{array}$ & $\begin{array}{l}\text { (identitásomat) és } \\
\text { nyomon követhetni } \\
\text { a digitális } \\
\text { adataimat (digitális } \\
\text { lábnyomomat). }\end{array}$ & $\begin{array}{l}\text { hallgatóság } \\
\text { számára. Képes } \\
\text { vagyok különféle } \\
\text { kommunikációs } \\
\text { formákat kezelni. } \\
\text { Aktívan osztok meg } \\
\text { információkat, } \\
\text { tartalmakat és } \\
\text { erőforrásokat } \\
\text { másokkal az online } \\
\text { közösségi térben és } \\
\text { kollaboratív } \\
\text { platformokon. } \\
\text { Aktívan részt } \\
\text { veszek az online } \\
\text { terekben. Különféle } \\
\text { online } \\
\text { szolgáltatásokat } \\
\text { használok. }\end{array}$ \\
\hline $\begin{array}{l}\text { Tartalom- } \\
\text { létrehozás }\end{array}$ & $\begin{array}{l}\text { Tudok egyszerü, } \\
\text { digitális } \\
\text { tartalmakat } \\
\text { készíteni (pl.. } \\
\text { szöveget, } \\
\text { táblázatot, képet, } \\
\text { hanganyagot stb.). } \\
\text { Képes vagyok } \\
\text { alapvető } \\
\text { módosításokat } \\
\text { végezni mások } \\
\text { által készített } \\
\text { tartalmakon. } \\
\text { Módosítani tudom } \\
\text { a szoftverek és } \\
\text { applikációk } \\
\text { egyszerü } \\
\text { funkcióit az } \\
\text { alapbeállítások } \\
\text { használatával. }\end{array}$ & $\begin{array}{l}\text { Különböző } \\
\text { formátumokban } \\
\text { tudok digitális } \\
\text { tartalmakat } \\
\text { elöállítani. Képes } \\
\text { vagyok } \\
\text { szerkeszteni és } \\
\text { finomításokat } \\
\text { végezni mások által } \\
\text { készített } \\
\text { tartalmakon. } \\
\text { Alapvető } \\
\text { ismereteim vannak } \\
\text { a szerzői jogi, a } \\
\text { copyleft és a } \\
\text { creative } \\
\text { commonsbeli } \\
\text { különbségekről. } \\
\text { Képes vagyok } \\
\text { bizonyos licenceket }\end{array}$ & $\begin{array}{l}\text { Különféle } \\
\text { formátumokban, } \\
\text { plattformokon és } \\
\text { különféle } \\
\text { környezetekben } \\
\text { tudok digitális } \\
\text { tartalmakat } \\
\text { elöállítani. Számos } \\
\text { digitális eszközt } \\
\text { tudok használni } \\
\text { saját } \\
\text { médiatartalmak } \\
\text { elöállításához. } \\
\text { Képes vagyok } \\
\text { meglévő tartalmi } \\
\text { elemek } \\
\text { összeszerkesztéséve } \\
1 \text { új tartalmak } \\
\text { létrehozására. } \\
\text { Tudom, hogyan kell }\end{array}$ \\
\hline
\end{tabular}




\begin{tabular}{|c|c|c|c|}
\hline & A alapszint & B középszint & C haladó szint \\
\hline & $\begin{array}{l}\text { Tudom, hogy az } \\
\text { általam talált } \\
\text { tartalmak szerzői } \\
\text { jogvédelem alatt } \\
\text { állhatnak. }\end{array}$ & $\begin{array}{l}\text { alkalmazni a } \\
\text { tartalmakra. } \\
\text { Különféleképpen } \\
\text { tudok } \\
\text { módosításokat } \\
\text { végezni a } \\
\text { szoftverekben és } \\
\text { applikációkban } \\
\text { speciális } \\
\text { beállításokat és az } \\
\text { alapvető program } \\
\text { beállításokat } \\
\text { használva. }\end{array}$ & $\begin{array}{l}\text { a különböző } \\
\text { licenceket } \\
\text { alkalmazni az } \\
\text { információkra és } \\
\text { forrásokra, } \\
\text { használom azokat. } \\
\text { Befolyásolni tudom } \\
\text { nyitott programok } \\
\text { müködését, } \\
\text { forráskódokat tudok } \\
\text { módosítani és írni. } \\
\text { Tudok kódolni és } \\
\text { programozni } \\
\text { különféle } \\
\text { nyelveken. Értem a } \\
\text { rendszerek } \\
\text { müködését és a } \\
\text { programok mögött } \\
\text { álló funkciókat. }\end{array}$ \\
\hline Biztonság & $\begin{array}{l}\text { Képes vagyok } \\
\text { alapvető lépéseket } \\
\text { tenni az } \\
\text { eszközeim } \\
\text { védelme } \\
\text { érdekében (pl.: } \\
\text { vírusirtók és } \\
\text { jelszavak } \\
\text { használata). } \\
\text { Tudom, hogy } \\
\text { csak bizonyos } \\
\text { típusú } \\
\text { információkat } \\
\text { oszthatok meg } \\
\text { magamról és } \\
\text { másokról online } \\
\text { környezetben. } \\
\text { Tudom, hogyan } \\
\text { lehet elkerülni a } \\
\text { számítógépes }\end{array}$ & $\begin{array}{l}\text { Tudom, hogyan } \\
\text { kell megvédenem a } \\
\text { digitális } \\
\text { eszközeimet. } \\
\text { Felülvizsgálom, és } \\
\text { ha szükséges } \\
\text { frissítem a } \\
\text { biztonsági } \\
\text { stratégiáimat. } \\
\text { Általános } \\
\text { ismereteim vannak } \\
\text { az adatvédelmi } \\
\text { kérdésekről és } \\
\text { alapvető } \\
\text { ismeretekkel } \\
\text { rendelkezem az } \\
\text { adatgyüjtés } \\
\text { módjáról és a } \\
\text { gyüjtött adatok } \\
\text { használatáról. }\end{array}$ & $\begin{array}{l}\text { Gyakran frissítem } \\
\text { biztonsági } \\
\text { stratégiáimat. } \\
\text { Intézkedem, ha az } \\
\text { eszközeim } \\
\text { veszélyben vannak. } \\
\text { Gyakran } \\
\text { megváltoztatom az } \\
\text { online } \\
\text { szolgáltatások } \\
\text { alapértelmezett } \\
\text { adatvédelmi } \\
\text { beállításait, hogy } \\
\text { javítsam a } \\
\text { magánéletem } \\
\text { védelmét. } \\
\text { Széleskörü a } \\
\text { tájékozottságom az } \\
\text { adatvédelmi } \\
\text { kérdések terén, és }\end{array}$ \\
\hline
\end{tabular}




\begin{tabular}{|c|c|c|c|}
\hline & A alapszint & B középszint & C haladó szint \\
\hline & $\begin{array}{l}\text { zaklatásokat. } \\
\text { Tudom, hogy a } \\
\text { technológia } \\
\text { veszélyt jelenthet } \\
\text { az egészségemre. } \\
\text { Alapvető } \\
\text { intézkedéseket } \\
\text { teszek az } \\
\text { energiatakarékoss } \\
\text { ág érdekében. }\end{array}$ & $\begin{array}{l}\text { Tudom, hogyan } \\
\text { védhetem meg } \\
\text { magam és mások } \\
\text { magánéletét a cyber } \\
\text { zaklatások ellen. } \\
\text { Megértem az } \\
\text { egészségügyi } \\
\text { kockázatokat a } \\
\text { technológia } \\
\text { használata kapcsán } \\
\text { az ergonómiai } \\
\text { szempontoktól } \\
\text { kezdve a } \\
\text { függőségig. } \\
\text { Ismerem a } \\
\text { technológia a } \\
\text { környezetre } \\
\text { gyakorolt pozitív és } \\
\text { negatív hatásait. }\end{array}$ & $\begin{array}{l}\text { tudom, hogyan } \\
\text { gyüjtenek rólam } \\
\text { adatokat és miként } \\
\text { használják fel } \\
\text { azokat. Tisztában } \\
\text { vagyok azzal, hogy } \\
\text { a technológiákat } \\
\text { megfelelően } \\
\text { alkalmazzák az } \\
\text { egészségügyi } \\
\text { problémák } \\
\text { elkerülésére. } \\
\text { Tudom, hogyan } \\
\text { lehet jó egyensúlyt } \\
\text { találni az online és } \\
\text { az offline világ } \\
\text { között. Jól } \\
\text { tájékozott vagyok a } \\
\text { technológiák } \\
\text { hatásairól a } \\
\text { mindennapi életre, } \\
\text { az online } \\
\text { fogyasztásra és a } \\
\text { környezetre } \\
\text { vonatkozóan. }\end{array}$ \\
\hline $\begin{array}{l}\text { Probléma- } \\
\text { megoldás }\end{array}$ & $\begin{array}{l}\text { Célzott } \\
\text { támogatást és } \\
\text { segítségnyújtást } \\
\text { tudok kérni, } \\
\text { amikor a } \\
\text { technológiák nem } \\
\text { müködnek } \\
\text { megfelelően vagy } \\
\text { amikor új eszközt, } \\
\text { programot vagy } \\
\text { alkalmazást } \\
\text { használok. } \\
\text { Néhány } \\
\text { rutinfeladat }\end{array}$ & $\begin{array}{l}\text { Megoldok apró } \\
\text { problémákat, } \\
\text { amelyek akkor } \\
\text { merülnek fel, } \\
\text { amikor a } \\
\text { technológiák nem } \\
\text { müködnek. } \\
\text { Tisztában vagyok } \\
\text { azzal, mely } \\
\text { technológiákat } \\
\text { tudom alkalmazni } \\
\text { és melyeket nem. } \\
\text { Képes vagyok } \\
\text { megoldani nem }\end{array}$ & $\begin{array}{l}\text { Sokféle problémát } \\
\text { meg tudok oldani, } \\
\text { amelyek a } \\
\text { technológia } \\
\text { használatából } \\
\text { erednek. } \\
\text { Magabiztosan } \\
\text { választok eszközt, } \\
\text { applikációt, } \\
\text { szoftvert vagy } \\
\text { szolgáltatást olyan } \\
\text { feladatokhoz is, } \\
\text { amelyekben nem } \\
\text { vagyok járatos. }\end{array}$ \\
\hline
\end{tabular}




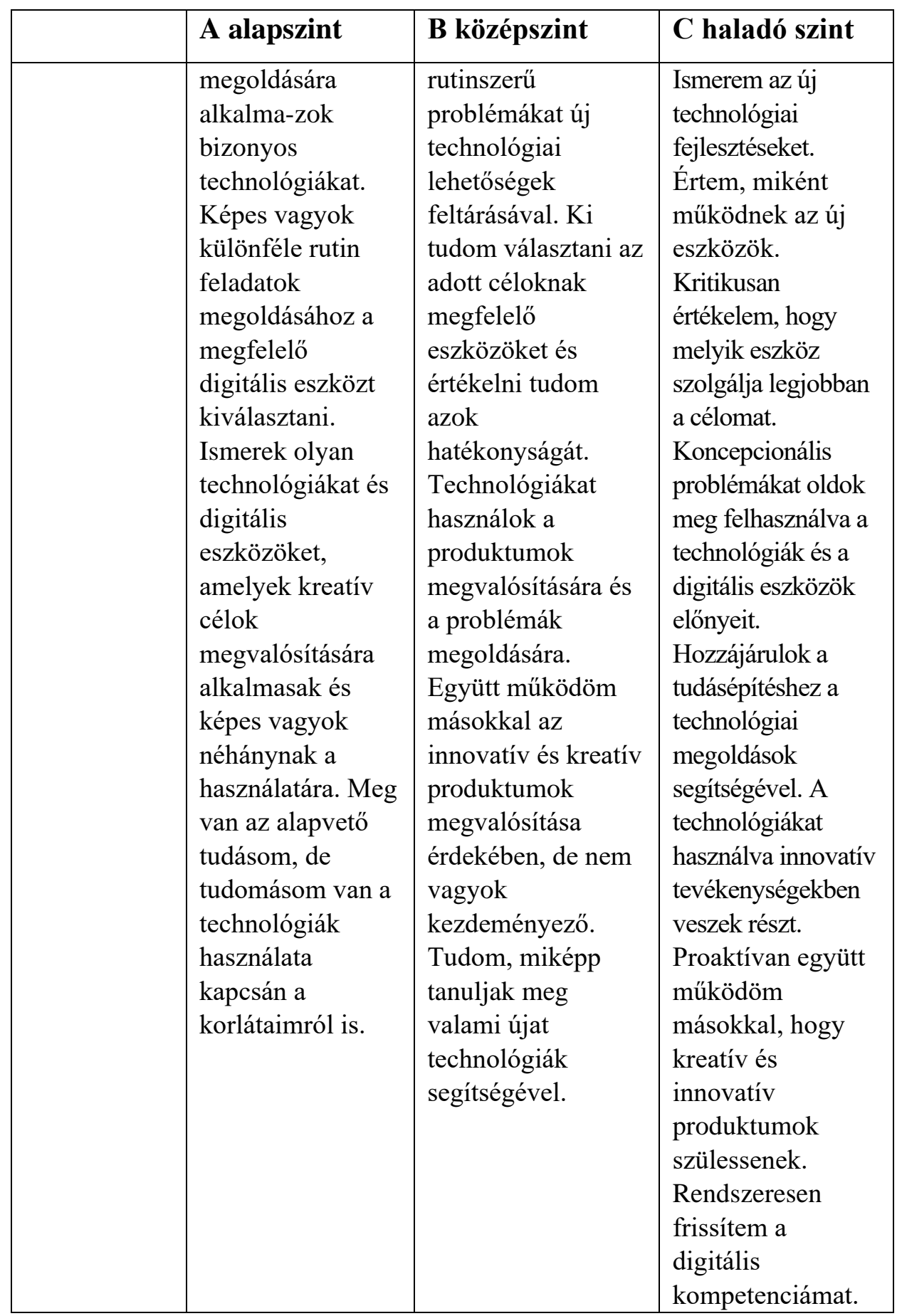

5. táblázat DIGCOMP önértékelési háló 


\section{A DIGCOMP 2.0}

2016-ban jelent meg a DigComp 2.0, amely néhány fontos elemmel bővítette a DigComp első változatát. A DigComp első változatát, a második változat megjelenésétől, DigComp 1.0-nak nevezik. A technológiai változások és a társadalom digitális elvárásai kényszerítették ki a DigComp második verziójának megszületését (Komposzt, 2016).

Változások a DigComp 1.0-hoz képest:

- 5 dimenzióból 4 dimenziója lett a keretrendszernek;

- a korábban meghatározott kompetenciaterületek elnevezései változtak (pontosabban az első háromé), s tartalmuk picit bővült;

- a 21 kompetencia jellegében megmaradt, viszont az elnevezések változtak, valamint újra lettek definiálva;

- néhány jelentős új fogalom bevezetésre került, mint például: adatmüveltség, digitális jólét;

- az új fogalmak bevezetésére létrejött egy szójegyzék, amelyben szómagyarázatok is vannak;

- a jártassági szintek módosultak, 3 jártassági szintből 8 lett;

- létrehoztak egy önértékelő referencia kérdőívet.

\subsection{DigComp 2.0 dimenziói}

5 dimenzió helyett már csak négy létezik, amelyek a következők:

1. dimenzió: Kompetenciaterületek (5);

2. dimenzió: Kompetenciák (21);

3. dimenzió: Jártassági szintek minden kompetenciához (8)

4. dimenzió: Tudásra, képességre és készségre példák.

\subsection{DigComp 2.0 kompetenciaterületek és kompetenciák módosulása}

A DigComp 2.0-ban a korábban meghatározott kompetenciaterületek közül az első három bővítése történt tehát elnevezésben, valamint e verzió már kitér az egyes kompetenciaelemekben való jártasságok szintjeire részletesebben is. 
$\mathrm{Az}$ 1. ábrán megtekinthető, miképp módosultak a kompetenciaterületek és kompetenciák elnevezései a DigComp 1.0-hoz képest. (Komposzt (2016).
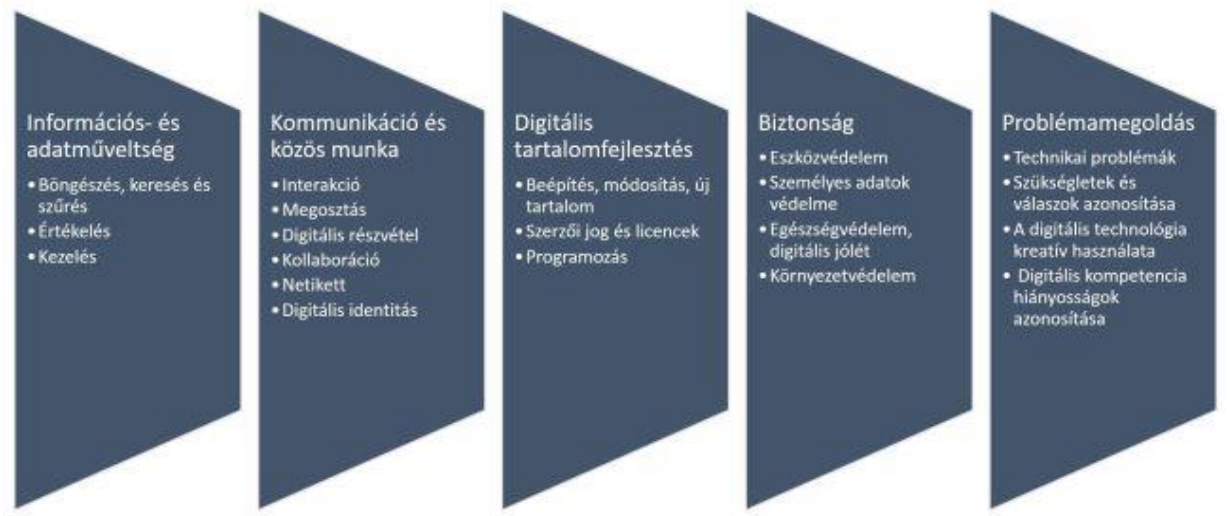

9. ábra Kompetenciaterületek és kompetenciák a Digcomp 2.0 szerint (forrás: Komposzt (2016): DigComp 2.0. In: k.o.m.p.o.s.z.t tanulás web, kettő, három... Portál. URL: https://bit.ly/2MyHwXQ, 2018.07.01.) $)^{3}$

\begin{tabular}{|l|l|}
\hline DIGCOMP 1.0 & DIGCOMP 2.0 \\
\hline 1. Információ & 1. Információs- és adatmüveltség \\
\hline 2. Kommunikáció & $\begin{array}{l}\text { 2. Kommunikáció és közös } \\
\text { munka }\end{array}$ \\
\hline 3. Tartalomlétrehozás & 3. Digitális tartalomfejlesztés \\
\hline 4. Biztonság & 4. Biztonság \\
\hline 5. Problémamegoldás & 5. Problémamegoldás \\
\hline
\end{tabular}

\section{6. táblázat A DigComp 1.0 és a Digcomp 2.0 közötti különbségek a kompetenciaterületeken}

A 21 kompetencia lényegében megmaradt, csak pici változások történtek az elnevezésekben, valamint újra lettek tartalmilag értelmezve. A DigComp 2.0 változatáról szóló angol dokumentum címe, amely a DigComp 1.0-ás dokumentumhoz hasonlóan szintén a Joint Research Center kiadványaként jelent meg: DigComp 2.0: The Digital Competence Framework for Citizens (Vourikari-Punie-Carretero-Brande, 2016). Emellett angol nyelven megtalálható egy rövid összefoglaló is a DigComp 2.0 tartalmáról a Europian Commission webportálon. (Europian Commission, é.n. b.). A kompetenciák esetében az elnevezések úgy módosultak, hogy a korábbi verzióban használt információ szó helyett az új változatban az ,adatok, információk és digitális tartalmak" kifejezéseket használják a tevékenységek megfogalmazásánál.

3 Hiányzik a programozás az ábrán a Digitális tartalomfejlesztés kompetenciaterület alól. 


\subsection{A kompetenciák elnevezéseinek változásai}

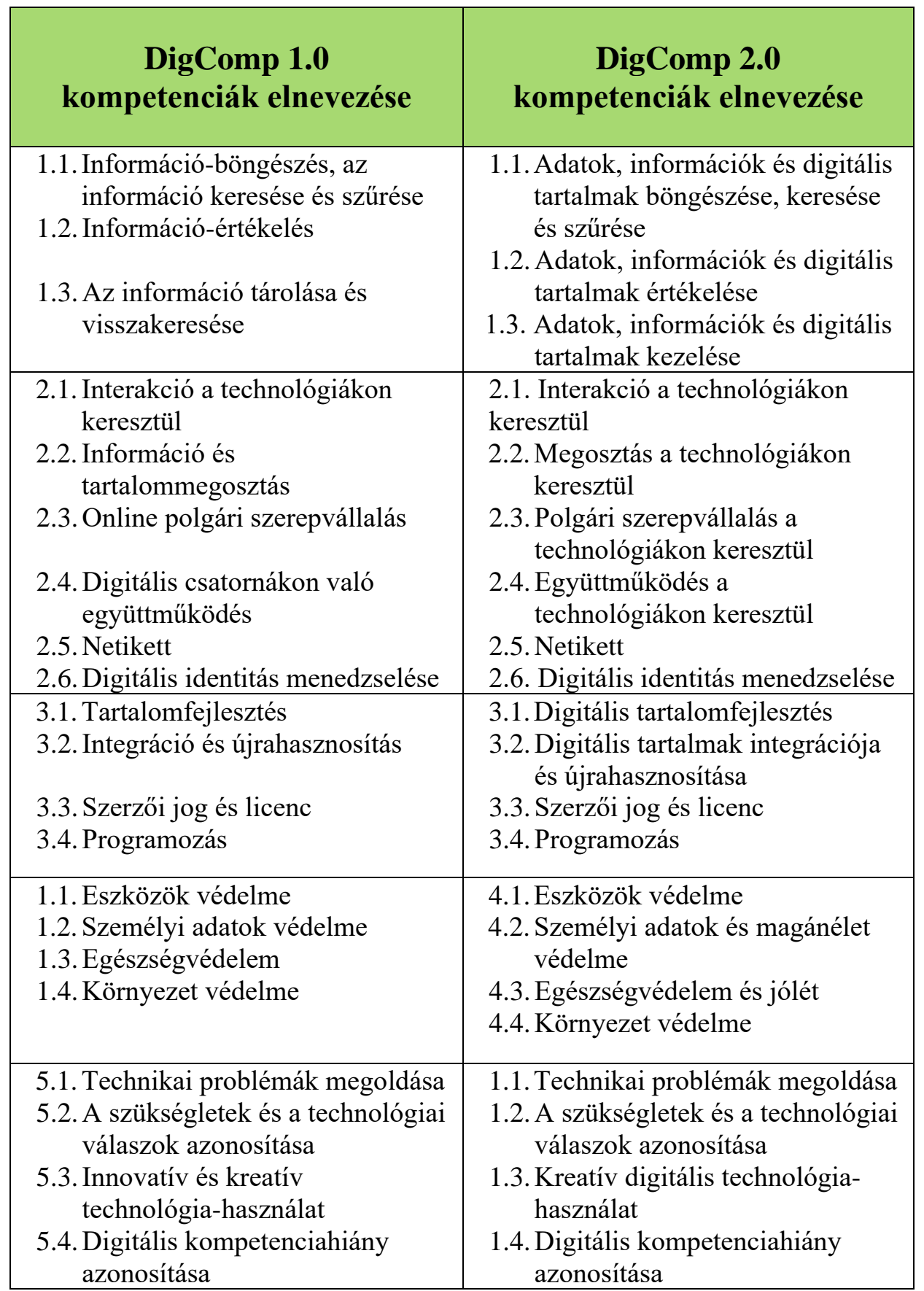

7. táblázat A DigComp 1.0 és a Digcomp 2.0 közötti különbségek a kompetenciák elnevezéseiben 


\section{Irodalomjegyzék}

Anusca Ferrari (2013): DIGCOMP: A Framework for Developing and Understanding Digital Competence in Europe. Joint Research Center. URL: https://bit.ly/23osQI7, 2018.07.01.

Europian Parliament and Council (2006): Recommendation of the Europian Parliament and of the council of 18 December 2006 on key competences for lifelong learning. Official Journal of the European Union. URL: https://bit.ly/2KZXghq, 2018.07.01.

Europian Commission (é.n.): Kompetenciák. In: Europian Commission Portal. URL: https://bit.ly/2PgA4Pq, 2018.07.01.

Komposzt (2016): DigComp 2.0. In: k.o.m.p.o.s.z.t tanulás web, kettő, három... Portál. URL: https://bit.ly/2MyHwXQ, 2018.07.01.

Wadmin (2009): Az egész életen át tartó tanuláshoz szükséges kulcskompetenciák. In Oktatáskutató és Fejlesztő Intézet Portálja. URL: https://bit.ly/2jeubnL, 2018.07.01.

Europian Commission (é.n. b): The Digital Competence Framework 2.0. In: Europian Commission Portal. URL: https://bit.ly/2vxeWKn, 2018.07.01.

Vourikari-Punie-Carretero-Brande (2016): DigComp 2.0: The Digital Competence Framework for Citizens. Joint Research Center. URL: https://bit.ly/21320Fl, 2018.07.01. 